\title{
Application of Rain Water Harvesting Scheme in Shimla Region
}

\author{
Rajiv Ganguly ${ }^{*}$, Bansal A, Mishra M and Kumar A \\ Department of Civil Engineering, Jaypee University of Information Technology (JUIT), Waknaghat, District Solan, Himachal Pradesh, India \\ ${ }^{*}$ Corresponding author: Ganguly R, Department of Civil Engineering, Jaypee University of Information Technology (JUIT), Waknaghat, District Solan, Himachal \\ Pradesh, India, Tel: +91-1792-239412; E-mail: rajiv.ganguly@juit.ac.in
}

Rec date: Jul 26, 2014; Acc date: Aug 27, 2014; Pub date: Sep 07, 2014

Copyright: (c) 2014 Ganguly R, et al. This is an open-access article distributed under the terms of the Creative Commons Attribution License, which permits unrestricted use, distribution, and reproduction in any medium, provided the original author and source are credited.

\begin{abstract}
Rainwater harvesting is an innovative and a suitable alternative approach of water supply that can be used by anyone. Rainwater harvesting captures, diverts, and stores rainwater for later use. It is a well known fact that during summer season there is a huge scarcity of water in northern regions of India and as such implementing rainwater harvesting would be beneficial because it would reduce demand on existing water supply reduces run-off, erosion, and also contamination of surface water. A rainwater harvesting system can range in size and complexity. All systems have basics components, which include a catchment surface, conveyance system, storage, distribution, and treatment. As such, we discuss in this paper about the prospects and possibilities of rainwater harvesting in Shimla region of Himachal Pradesh, which experience water shortages in summer periods due to increase in population and also climatic conditions. The result of our study shows that judicious storing of rain water all round the year and not only summer can be stored without incurring any significant losses. Further, the study shows that the sanitation water requirements for a family can be met for two months with storage of rainwater for one single month only. Further, the construction pattern of houses in Shimla (sloped roof structures) already provides an advantage in storing rainwater efficiently. The non-dimensional design parameters can be applied for any place which experiences a scarcity of water. The paper also presents a simple benefit-cost ratio for the designed rainwater harvesting system.
\end{abstract}

Keywords: Rainwater harvesting; Shimla; Demand fraction; Storage fraction

\section{Introduction}

The world faces escalating demands for good quality of water in the future as current demand from surface and ground water supplies continue to dwindle. Even in those areas that appear to have adequate water supply, there is a constant need to balance the existing water supply with ever growing demands.

Droughts experienced by those regions having scarcity of water supply bring into perspective the need to conserve, protect and supplement existing water supplies. Rainwater harvesting structures have been successfully implemented in semi-arid, dry and sub-humid regions which often experiences water scarcity due to significant variation in rainfall instead of the total volume of rainfall. Due to such conditions high rainfall intensities coupled with lesser frequency of rainfalls and poor spatio-temporal distribution of rainfall, even if total volume of rainfall is sufficient leads to huge amount of rainfall water loss leading to scarcity of water [1]. Further, with the increase in frequency of dry spells attributed to change in climatic pattern over the water, the IPCC report [2] suggested use of rainwater harvesting for increasing agricultural production.

In India, the importance of groundwater recharge in dry state like Rajasthan is very important particularly as about $70 \%$ population in Rajasthan depend on groundwater for drinking and irrigation purposes [3]. In such scenarios, the collection and storage of rainwater to supplement existing water supply sources could alleviate some of these problems. As such, rainwater utilization is one of the best available methods for recovering natural hydrological cycles and aiding in sustainable urban development [4].
Water scarcity demands the maximum use of every drop of rainfall. Rainwater harvesting system has been considered as a suitable alternative water source for increasing water supply capacities [5]. The collection of rainwater and its utilization to supplement demand for those regions unable to cope with potable water needs seems to be a feasible option as rainwater is one of the purest sources of water available and contains very low impurities. Rainwater harvesting systems can be adopted where conventional water supply systems have failed to meet people's water demands [6]. Rainwater harvesting is defined as the process of intercepting rainwater in hydrologic cycle through either natural landforms or artificial facilities and its collection and storage for later productive use. The term water harvesting refers to collection and storage of natural precipitation and also other activities aimed at harvesting surface and groundwater, prevention of losses through evaporation and seepage and all other hydrological studies, aimed at conservation and efficient utilization of the limited water endowment of a physiographic unit, such as a watershed. Rainwater harvesting is one of the most economical and practical measures for providing supplementary water supplies with its easy system installation. It can be a supplementary water source in urbanized regions for miscellaneous household uses such as toilet flushing, lawn watering, landscape and ecological pools, and cooling for air conditioning [7].

Rainwater harvesting scheme has been a long followed process in India. Traditional methods of rainwater harvesting system in India includes 'Kunds' of Thar Desert followed in Thar Desert in Rajasthan, 'Bamboo drip Irrigation' in Northeastern Hills and 'Kul Irrigation' scheme in Trans-Himalayan Region [8].

Interestingly studies have shown that those regions experiencing sufficient amount of rainfall may experience scarcities in water at those 
Page 2 of 11

locations, as demand exceeds supply [9]. As such one of the proposed solutions to minimize the demand-supply gap is to augment the existing supply by rainwater harvesting. Rainwater Harvesting has found varied applications in India from recharging ground water in Rajasthan $[3,10]$ to its application as a major alternative to conventional river basin water resource development models $[11,12]$. One of the highly admired and recognized systems of implementation of Rainwater Harvesting has been implemented in Raj Samadhiyala village of Saurashtra near Rajkot. It initially commenced as a local initiative, and benefitted from the support of private voluntary organization of 'Jal Dhara Trust' [13]. The study reported that there was a substantial yield in growth of vegetables and farmer incomes along with high water efficiency, reduction in cost of production and higher productivity.

North Eastern States in India experience some of the highest rainfall in the country and hence is aptly suited for the implementation of Rainwater Harvesting Scheme. As per reports, more than 100 rainwater harvesting schemes are being run in the seven sister states with the majority of such projects being concentrated in Mizoram and Nagaland [14]. Generally rooftop rainwater harvesting scheme is followed for storing rainwater during scarce periods. The stored rainwater harvesting is first utilized for cooking and drinking purposes after first flush system and filtration to remove debris and contaminants for their purpose before being diverted to storage tank and stored in large quantities in lined ponds. One important consideration of high importance is the ideal tank size and the affordability of such a tank. These storage ponds are generally lined with non-permeable sheets like HDPE and nylon to minimize seepage losses and the stored water is used for irrigation purposes. To calculate the storage requirement hydraulic parameters like effective rainfall, evaporation, runoff coefficient will be necessary for designing the storage pond [15].

A review of the literature suggests that majority rainwater harvesting benefit-cost analyses involved its impacts on agricultural applications and benefits drawn from them [16-18].This paper applies the concept of the rainwater harvesting for two locations including its system design for JUIT campus and for the city of Shimla and show how water harvesting system can alleviate a certain portion of water demand of the people as shown through these two case studies. Similar methodology was followed for both case studies. A benefit-cost ratio was done to determine the effectiveness of the proposed rainwater harvesting system.

\section{Methodology}

A schematic illustration of the rainwater harvesting system used for both the case studies has been shown in Figure 1. From the schematics of the diagram presented in Figure 1, the maximum supply of rainwater can be computed as the volume of water stored in the tank along with additional inflow in the tank. The inflow (Q) to the tank depends on precipitation (R), catchment area (A) and runoff coefficient $(\mathrm{k})$. Mathematically, the relationship can be expressed as

$$
Q=k R A
$$

The rainfall-runoff process is often interpreted by assuming a constant runoff coefficient and no quality aspects are taken into account thus neglecting the occurrence of the first flush phenomenon. The impact of pollutant load associated with urban paved surfaces is often significant thus requiring at least diverting the first flush volume [19]. Various considerations have been put forward to consider the first flush volume. For examples, first $0.33 \mathrm{~mm}$ of daily rainfall can be subtracted [20] while $0.4 \mathrm{~mm}$ of first flush occurring after 3 dry days can also be subtracted [21].

\begin{tabular}{|c|c|}
\hline Area Description & Runoff Coefficient K \\
\hline \multicolumn{2}{|l|}{ Business } \\
\hline Downtown & $0.70-0.95$ \\
\hline Neighborhood & $0.50-0.70$ \\
\hline \multicolumn{2}{|l|}{ Residential } \\
\hline Single-Family & $0.30-0.50$ \\
\hline Multiunits, detached & $0.40-0.60$ \\
\hline Multiunits, attached & $0.60-0.75$ \\
\hline Residential (suburban) & $0.25-0.40$ \\
\hline Apartment & $0.50-0.70$ \\
\hline \multicolumn{2}{|l|}{ Industrial } \\
\hline Light & $0.50-0.80$ \\
\hline Heavy & $0.60-0.90$ \\
\hline Parks, cemeteries & $0.10-0.25$ \\
\hline Playgrounds & $0.20-0.35$ \\
\hline Railroad yard & $0.20-0.35$ \\
\hline Unimproved & $0.10-0.30$ \\
\hline Character of surface & Runoff Coefficient K \\
\hline \multicolumn{2}{|l|}{ Pavement } \\
\hline Asphaltic and concrete & $0.70-0.95$ \\
\hline Brick & $0.70-0.85$ \\
\hline Roofs & $0.75-0.95$ \\
\hline \multicolumn{2}{|l|}{ Lawns, sandy soil } \\
\hline Flat, 2 percent & $0.05-0.10$ \\
\hline Average, 2-7 percent & $0.10-0.15$ \\
\hline Steep, 7 percent & $0.15-0.20$ \\
\hline \multicolumn{2}{|l|}{ Lawns, heavy soil } \\
\hline Flat, 2 percent & $0.13-0.17$ \\
\hline Average, 2-7 percent & $0.18-0.22$ \\
\hline Steep, 7 percent & $0.25-0.35$ \\
\hline
\end{tabular}

Table 1: Values of run-off coefficient for different types of area and character of surfaces

In our present case studies it is assumed that rainwater is only collected from rooftops and balconies and since the pollutant load washed-off from such surfaces is much less compared to road runoff [22], the effect of first flush has been considered particularly because of debris, bird droppings or tiny plastic materials used for painting which 
Citation: Ganguly R, Bansal A, Mishra M, Kumar A (2014) Application of Rain Water Harvesting Scheme in Shimla Region. Hydrol Current Res

Page 3 of 11

will be washed away with the first flush. For our case studies, we have selected runoff coefficient values to be 0.85 in both cases. Table 1 provides the detailed suggested runoff coefficient values depending upon different factors.

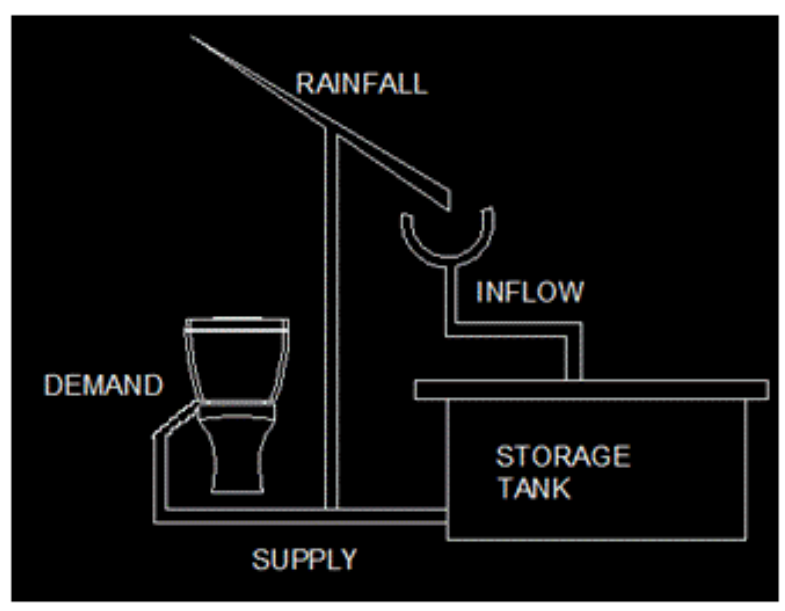

Figure 1: Configuration of the rainwater harvesting system

A rainwater harvesting system usually consists of three basic elements: the catchment system, the conveyance system, and the storage system. The determination of benefit-cost ratio involved all these three components to see the suitability of the application of the rainwater harvesting system.

\section{Case Studies}

\section{Case study I: JUIT campus}

\section{Site description}

Jaypee University of Information Technology (JUIT) is situated in the hilly terrain of Waknaghat in district Solan in Himachal Pradesh. The total strength on campus is about of 3500 comprising of students, faculty, workers and staff.

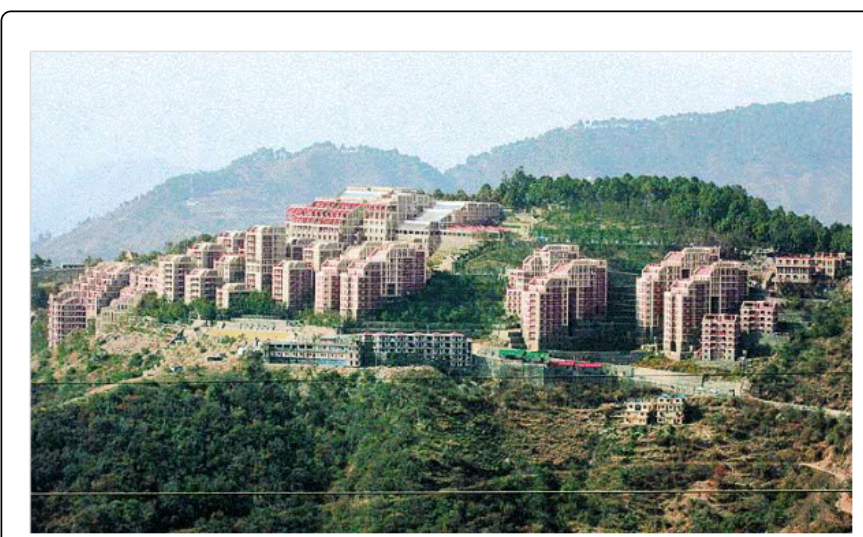

Figure 2: An overview of JUIT campus
Rainfall is common in months of July to September. At present, to cater to the existing water demand of the institution, it is being partially satisfied by water tankers and rest by pump house situated at Domehar Bani located at a distance of about $3 \mathrm{~km}$ from JUIT campus. Figure 2 shows the overall campus details of JUIT.

The campus has four residential quarters (A-D). The numbers of flats in each of these blocks are 7,24, 21 and 20 hence the total number of residential quarters is 72 (Figures 3-5). Assuming that number of occupants in each flat is 4 , the total number of people for which the rainwater harvesting system was to be designed was 288 .

\section{Design analysis}

The design population is 288 and it is assumed that the estimated water demand is 150 liters/per/capita/day (lpcd). Further since the university is closed for one month during summer, it is assumed that the water requirement will be required only for 11 months (or 330 days). Using this information, the total amount of water consumed annually will be 14256000 liters or $14256 \mathrm{~m}^{3}$.

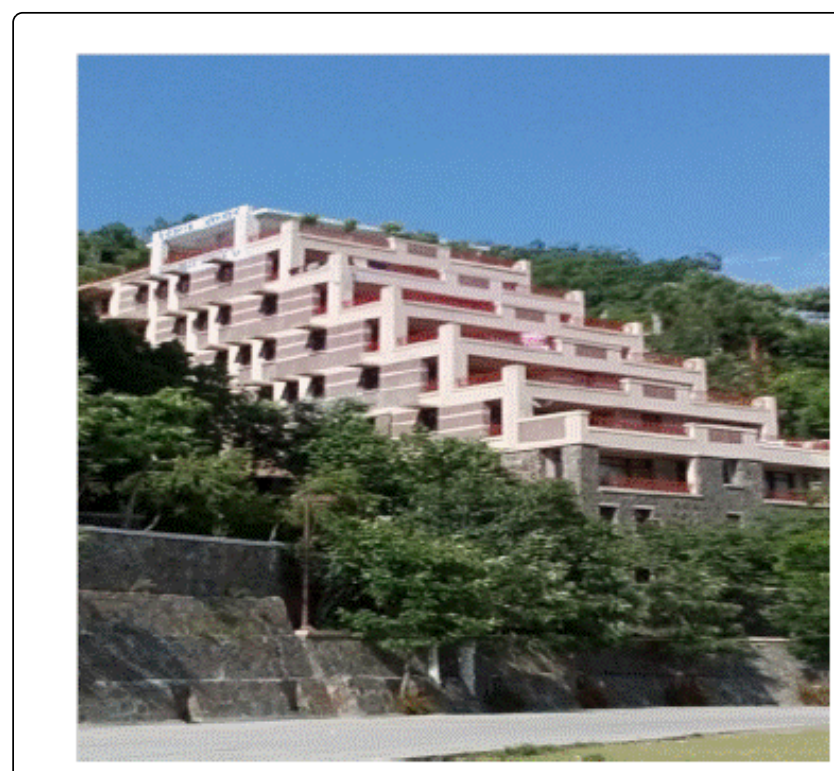

Figure 3: A-block of JUIT (7 flats)

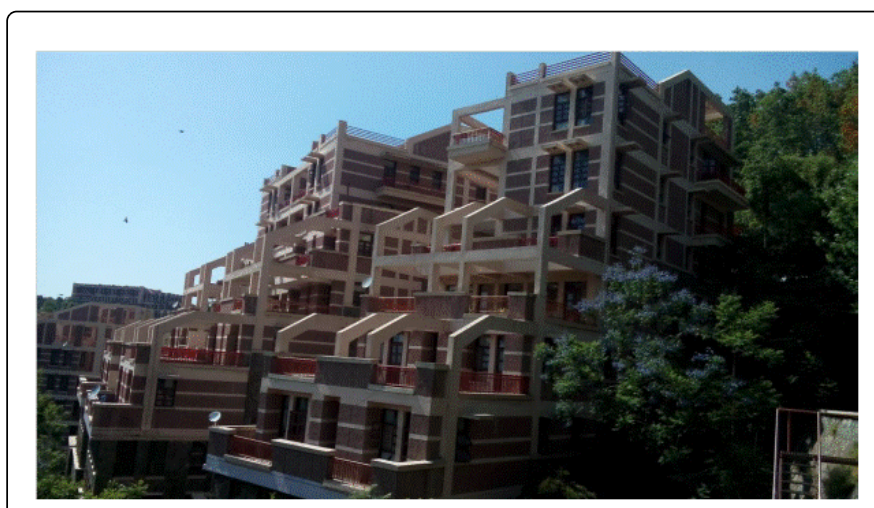

Figure 4: B-block of JUIT (24 flats) 


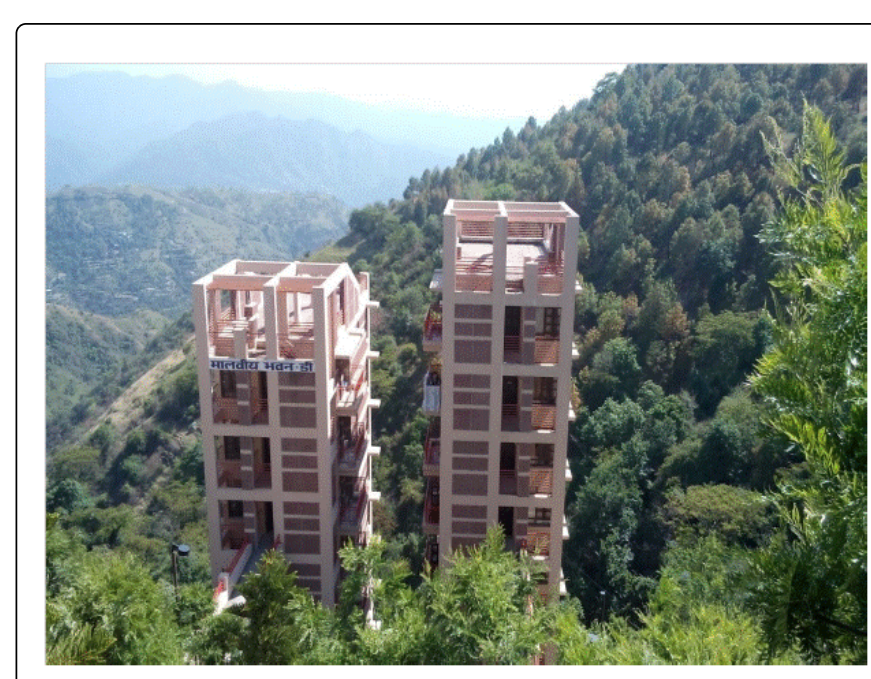

Figure 5: D-block of JUIT (20 flats)

\begin{tabular}{|l|l|}
\hline Months & Rainfall (mm) \\
\hline January & 39.19 \\
\hline February & 42.86 \\
\hline March & 36.73 \\
\hline April & 31.5 \\
\hline May & 37.55 \\
\hline June & 125.13 \\
\hline July & 253.99 \\
\hline August & 226.51 \\
\hline September & 138.31 \\
\hline October & 18.4 \\
\hline November & 11.14 \\
\hline December & 15.58 \\
\hline Standard Deviation & 84.7 \\
\hline
\end{tabular}

Table 2: Monthly average rainfall for period 1900 to 2012

The catchment area was determined to be the summation of total roof area and the balcony area. While the balcony area was computed only for the residential blocks, the total roof area was computed for both residential and non-residential buildings located within the campus. The total catchment area was calculated to be $1724 \mathrm{~m}^{2}$. Monthly rainfall data was obtained for a period of one complete century and the average rainfall data was found to be $977 \mathrm{~mm}$ and this has been shown in Table 2. Assuming runoff coefficient of 0.85 and evaporation losses of 0.80 , the total amount rainwater harvested was found to be 1145356 liters or $1146 \mathrm{~m}^{3}$ annually. The rainwater harvested fulfilled only $8 \%$ of the total water requirement annually.

A mass curve analysis of the total water requirement versus the total rainwater harvested was plotted and is shown in Figure 6. The mass curve obtained shows that water demand is much greater than the water supplied or harvested. So, we redesigned our water demand requirement for other household purpose like sanitation, washing etc. for using the harvested rainwater.

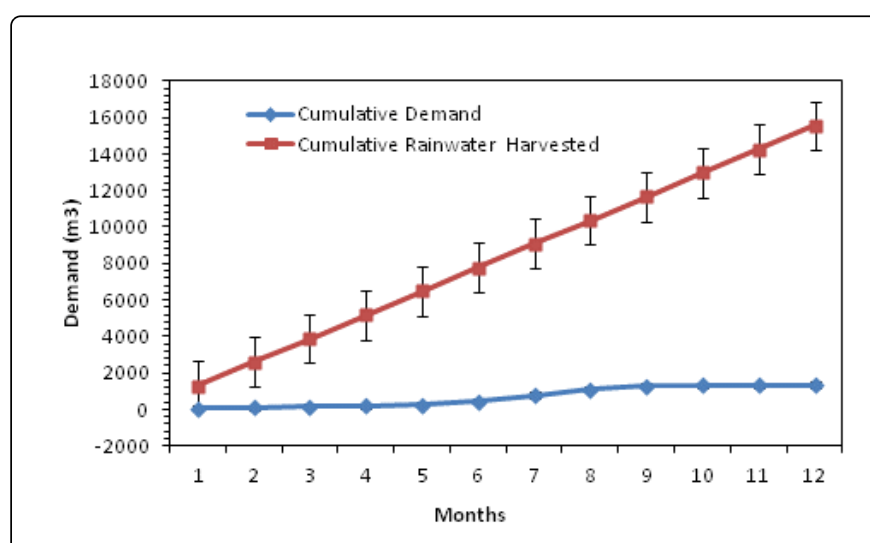

Figure 6: Mass Curve of Cumulative Demand vs. Cumulative rainwater harvested assuming water demand as $150 \mathrm{lpcd}$

For redesigning the water requirement, it is assumed that the design population remains same and that the estimated water demand is 40 lpcd for sanitation and washing purposes. Assuming all other conditions remain the same the total amount of water consumed annually will be 3801600 liters or $3802 \mathrm{~m}^{3}$. The rainwater harvested fulfilled now $30 \%$ of the total water requirement for sanitation and washing purposes.

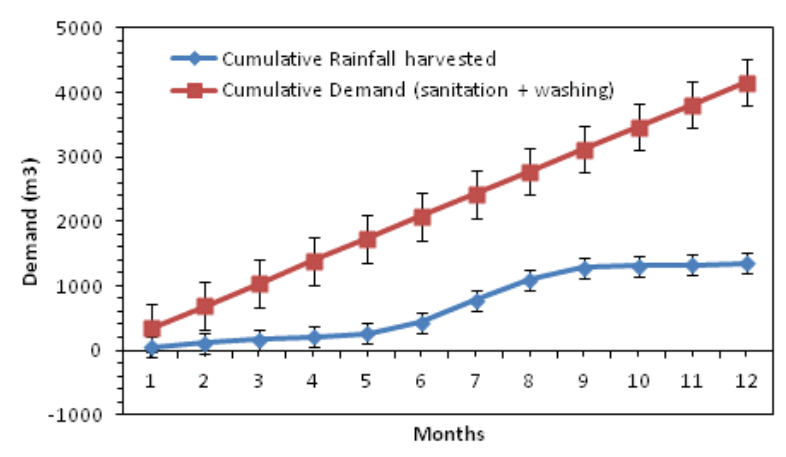

Figure 7: Mass Curve of Cumulative Demand vs. Cumulative rainwater harvested assuming water demand as $40 \mathrm{lpcd}$ for sanitation and washing purposes.

A revised mass curve analysis of the total water requirement for sanitation and washing purposes versus the total rainwater harvested was plotted and is shown in Figure 7. The mass curve obtained shows that water demand is much greater than the water supplied or harvested but is more suited for meeting sanitation and washing requirement than the overall water demand.

Hence, from our revised design analysis considering the requirement for sanitation and washing, if we only consider residential block $\mathrm{D}$, with a design population of 80 persons with an estimated water demand of $40 \mathrm{lpcd}$ for sanitation and washing purposes the total amount of water that will be consumed will be 1056000 litres or 1056 
$\mathrm{m}^{3}$. For such a design consideration, the rainwater harvested now fulfils the annual water requirement for sanitation and washing purposes in residential block D.

\section{Filtration system}

Filtration of rainwater is very important before storing it. Rooftop runoff may present tiny plastic materials used for painting which can cause serious issues. Further, dirt and other debris, if not filtered out, can cause blocks in the plumbing system when the stored rainwater is used. In practice, two levels of filtration are followed, coarse filtration and then fine filtration.

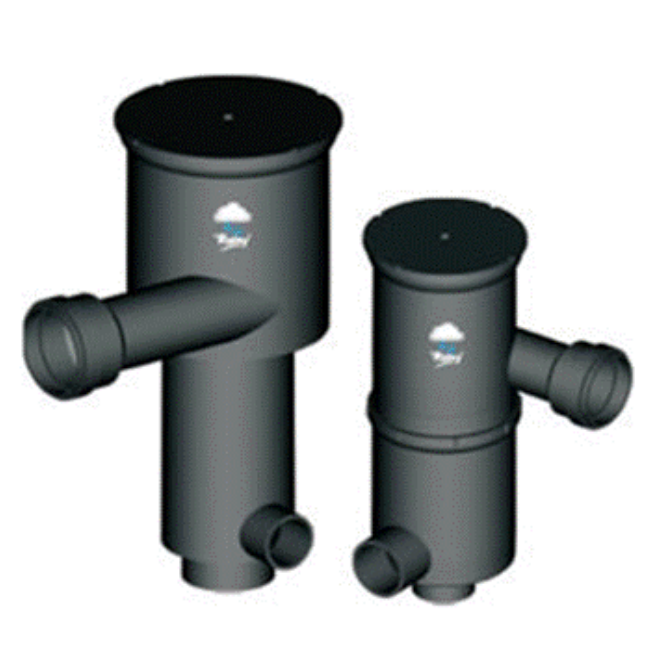

Figure 8: Primary Filtration Unit

The first level of filtration (Primary Filter) include a grating at the outlet of the catchment or the inlet of the gutters or down take pipes to prevent large coarse debris like leaves from entering the rainwater transportation and storage network. For open gutters, leaf guards, which are generally, mesh screens in wire frames may be installed along the length of the gutter. The rooftop must be regularly cleaned for the leaf screens to be effective, else the piled up leaves will clog the screen and prevent rainwater from entering the gutters or down take pipes. This can even result in leakage of water from the roof. If wire meshes or gratings are not used at the outlet of the catchment, the filtration system installed should be able to segregate such debris from the collected rainwater. An example of this type of filter is shown in Figure 8 .

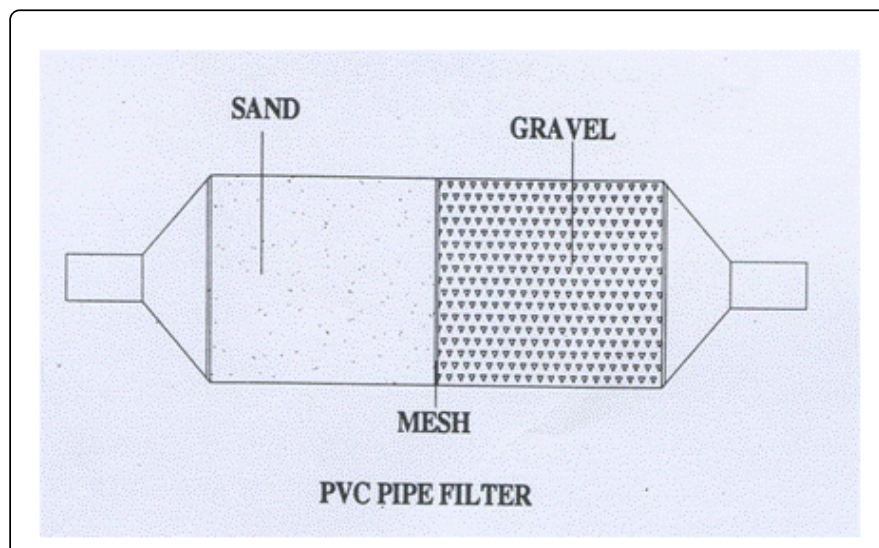

Figure 9: Secondary Filtration Unit

The fine filtration (Secondary Filter) technique involves a filter made by PVC pipe of 1 to $1.20 \mathrm{~m}$ length, and the diameter of the pipe depends on the area of roof. In practice, about six inch diameter pipe is enough to cater a 1500 square feet roof area and generally eight inch diameter pipe is preferred for roofs having area greater than 1500 square feet. Each component should be filled with gravel and sand alternatively as shown in the Figure 9. A layer of charcoal could also be inserted between two layers. Both ends of filter should have reduced of required size to connect inlet and outlet. This filter could be placed horizontally or vertically in the system.

\section{Water quality analysis of rainfall water}

Rainwater collection systems are commonly believed to provide good quality water without treatment because the collection surfaces (roofs) are isolated from many of the usual sources of contamination (e.g. sanitation systems). Although roofs are higher than the ground, dust and other debris can be blown onto them, leaves can fall from trees, and birds and climbing animals can defecate upon them. As such, these sorts of conditions can deteriorate the quality of water entering the storage tank. Table 3 highlights the types of contaminants found in rainwater collection systems [23].

\begin{tabular}{|l|l|l|}
\hline Contaminant & Source & Risk \\
\hline Dust and Ash & Surrounding dirt and vegetation & $\begin{array}{l}\text { Moderate: can be minimized be regular roof and gutter maintenance and } \\
\text { first flush conditions }\end{array}$ \\
\hline Pathogenic Bacteria & Bird and animal droppings on roof, attached to dust & $\begin{array}{l}\text { Moderate: Bacteria may be present in dust or in bird feces. Can be } \\
\text { minimized by first flushing's. }\end{array}$ \\
\hline Heavy Metals & $\begin{array}{l}\text { Roof materials or dust materials from urban and } \\
\text { industrialized area }\end{array}$ & $\begin{array}{l}\text { Low: Unless downwind of any industry or any manufacture processes like } \\
\text { metal smelter and/or very acidic rainfall }\end{array}$ \\
\hline $\begin{array}{l}\text { Other inorganic contaminants } \\
\text { (salt from sea spray) }\end{array}$ & $\begin{array}{l}\text { Sea spray, certain industrial discharges in air, use of } \\
\text { unsuitable tank and/or roof }\end{array}$ & $\begin{array}{l}\text { Low: Unless downwind of any large scale industry or in very near vicinity } \\
\text { of ocean }\end{array}$ \\
\hline Mosquito Larvae & Mosquitoes laying eggs in gutter & $\begin{array}{l}\text { Moderate: if tank inlet is screened and there are no gaps, risks can be } \\
\text { minimized }\end{array}$ \\
\hline
\end{tabular}

Table 3: Types of contaminants in rainwater harvesting systems 
Page 6 of 11

Various important water quality testing parameters including $\mathrm{pH}$, Turbidity, Hardness, Acidity, Alkalinity and Total Dissolved Solids (TDS) and chloride content were carried out, the results of which have been discussed later in Results and Discussions section.

\section{Benefit-cost analysis}

The total cost of constructing rainwater storing tanks for Blocks A$\mathrm{D}$ in JUIT campus is estimated to be INR 285753.32. This includes excavation, brickwork, PCC and cement plastering costs associated with construction of rainwater storing tanks. Table 4-7 provides the individual costs of different tanks associated with the different blocks A-D. Design costs associated with the conveyance systems for all the total blocks within JUIT campus are estimated to be INR 36022. The cost of estimating conveyance system for each individual block has been shown below.

\begin{tabular}{|r|l|l|l|l|l|}
\hline Item No. & Particular of items of work & $\begin{array}{l}\text { Quantit } \\
\mathbf{y}\end{array}$ & Unit & Rate & Amount \\
\hline $\mathbf{1}$ & Excavation in foundation \& Tank & 14.943 & $\mathrm{~m}^{3}$ & 100 & 1494.3 \\
\hline $\mathbf{2}$ & Brickwork & 5.9024 & $\mathrm{~m}^{3}$ & 6500 & 38365.6 \\
\hline $\mathbf{3}$ & PCC & 0.7936 & $\mathrm{~m}^{3}$ & 3600 & 2856.96 \\
\hline $\mathbf{4}$ & Cement Plaster & 29.76 & $\mathrm{~m}^{2}$ & 135 & 4017.6 \\
\hline & & & & $\begin{array}{l}\text { Tota } \\
\text { I }\end{array}$ & $\mathbf{4 6 7 3 4 . 4 6}$ \\
\hline
\end{tabular}

Table 4: Cost Estimation for Rainwater Harvesting Tank in Block-A (JUIT campus)

\begin{tabular}{|l|l|l|l|l|l|}
\hline Item No. & Particular of items of work & $\begin{array}{l}\text { Quantit } \\
\mathbf{y}\end{array}$ & Unit & Rate & Amount \\
\hline $\mathbf{1}$ & Excavation in foundation \& Tank & 42.61 & $\mathrm{~m}^{3}$ & 100 & 4261 \\
\hline $\mathbf{2}$ & Brickwork & 11.26 & $\mathrm{~m}^{3}$ & 6500 & 73190 \\
\hline $\mathbf{3}$ & PCC & 1.5136 & $\mathrm{~m}^{3}$ & 3600 & 5448.96 \\
\hline $\mathbf{4}$ & Cement Plaster & 56.76 & $\mathrm{~m}^{2}$ & 135 & 7662.6 \\
\hline & & & & $\begin{array}{l}\text { Tota } \\
\mathbf{I}\end{array}$ & $\mathbf{9 0 5 6 2 . 5 6}$ \\
\hline
\end{tabular}

Table 5: Cost Estimation for Rainwater Harvesting Tank in Block-B (JUIT campus)

\begin{tabular}{|r|l|l|l|l|l|}
\hline Item No. & Particular of items of work & Quantity & Unit & Rate & Amount \\
\hline $\mathbf{1}$ & Excavation in foundation \& Tank & 34.02 & $\mathrm{~m}^{3}$ & 100 & 3402 \\
\hline $\mathbf{2}$ & Brickwork & 10.586 & $\mathrm{~m}^{3}$ & 6500 & 68809 \\
\hline $\mathbf{3}$ & PCC & 1.19 & $\mathrm{~m}^{3}$ & 3600 & 4284 \\
\hline $\mathbf{4}$ & Cement Plaster & 59.68 & $\mathrm{~m}^{2}$ & 135 & 8056.8 \\
\hline & & & & $\begin{array}{l}\text { Tota } \\
\text { I }\end{array}$ & $\mathbf{8 4 5 5 1 . 8}$ \\
\hline
\end{tabular}

Table 6: Cost Estimation for Rainwater Harvesting Tank in Block-C (JUIT campus)

\begin{tabular}{|r|l|l|l|l|l|}
\hline Item No. & Particular of items of work & Quantity & Unit & Rate & $\begin{array}{l}\text { Amoun } \\
\mathbf{t}\end{array}$ \\
\hline $\mathbf{1}$ & Excavation in foundation \& Tank & 24.81 & cu.m & 100 & 2481 \\
\hline $\mathbf{2}$ & Brickwork & 8.016 & cu.m & 6500 & 52104 \\
\hline $\mathbf{3}$ & PCC & 1.19 & cu.m & 3600 & 4284 \\
\hline $\mathbf{4}$ & Cement Plaster & 37.3 & sq.m & 135 & 5035.5 \\
\hline & & & & Total & 63904.5 \\
\hline
\end{tabular}

Table 7: Cost Estimation for Rainwater Harvesting Tank in Block-D (JUIT campus)Total cost of building Rainwater Harvesting Tank for Blocks A-D = Rs 285753.32

\section{Cost Estimation for Conveyance System}

Block - A

Total Flats $=7$

Length of main pipe $=90 \mathrm{ft}$

Pipe length required for balcony (Since Balcony are in stepped manner) Total number of balconies $=4$

Length of pipe for top most balcony $=12 \mathrm{ft}$

Length of pipe for $2 \mathrm{nd}$ balcony from top $=9 \mathrm{ft}$

Length of pipe for 3rd balcony from top $=6 \mathrm{ft}$

Length of pipe for 4 th balcony from top $=3 \mathrm{ft}$

Total length of pipe required $=30+90=120 \mathrm{ft}=36.576 \mathrm{~m}$

Cost of $6 \mathrm{~m}$ pipe $=$ INR 529.20

Total Cost of pipe network for Block A = Rs.3226

Block - B

Total Flats $=24$ (6 flats in each tower)

Length of main pipe $=4 \times 80=320 \mathrm{ft}$

Pipe length required for balcony (Since Balcony are in stepped manner) Total number of balconies in one tower $=4$

Length of pipe for top most balcony $=12 \mathrm{ft}$

Length of pipe for 2nd balcony from top $=9 \mathrm{ft}$

Length of pipe for 3rd balcony from top $=6 \mathrm{ft}$

Length of pipe for 4 th balcony from top $=3 \mathrm{ft}$

Total length of pipes required for balcony $=30 \times 4=90 \mathrm{ft}$

Total length of pipe required $=120+320=440 \mathrm{ft}=134.112 \mathrm{~m}$

Cost of $6 \mathrm{~m}$ pipe $=$ INR 529.20

Total Cost of pipe network for Block B = Rs.11,828

Block - C

Total Flats $=21$ ( 7 flats in each tower)

Length of main pipe $=3 \times 90=270 \mathrm{ft}$

Pipe length required for balcony (Since Balcony are in stepped manner) Total number of balconies $=4$ 
Length of pipe for top most balcony $=12 \mathrm{ft}$ Length of pipe for $2 \mathrm{nd}$ balcony from top $=9 \mathrm{ft}$ Length of pipe for 3rd balcony from top $=6 \mathrm{ft}$ Length of pipe for 4th balcony from top $=3 \mathrm{ft}$

Total length of pipes required for balcony $=30 \times 3=90 \mathrm{ft}$

Total length of pipe required $=90+270=360 \mathrm{ft}=109.7272 \mathrm{~m}$

Cost of $6 \mathrm{~m}$ pipe $=$ INR 529.20

Total Cost of pipe network for Block C $=$ Rs.9678

Block - D

Total Flats $=20$ (10 flats in each tower $)$

Length of main pipe from one roof $=120 \mathrm{ft}$

Length of main pipe $=3 \times 120=360 \mathrm{ft}$

Pipe length required for balcony (Since Balcony are in stepped manner)

Total number of balconies $=4$

Length of pipe for top most balcony $=12 \mathrm{ft}$

Length of pipe for $2 \mathrm{nd}$ balcony from top $=9 \mathrm{ft}$

Length of pipe for $3 \mathrm{rd}$ balcony from top $=6 \mathrm{ft}$

Length of pipe for 4 th balcony from top $=3 \mathrm{ft}$

Total length of pipes required for balcony $=30 \times 2=60 \mathrm{ft}$

Total length of pipe required $=60+360=420 \mathrm{ft}=128 \mathrm{~m}$

Cost of $6 \mathrm{~m}$ pipe $=$ INR 529.20

Total Cost of pipe network for Block D = Rs.11290

Total cost of constructing conveyance system for Blocks A-D = Rs 36021 .

The total cost of filtration system for all the blocks (A-D) for JUIT campus was estimated to be INR 140150. The details have been provided below.

\section{Cost Estimation for Filtration System}

Filter units used are Coarse Mesh Filter \& FL Filter

For A Block - 1 Coarse mesh Filter and 2 FL Filter units are used

For B Block - 4 Coarse mesh Filter and 8 FL Filter units are used

For C Block - 3 Coarse mesh Filter and 6 FL Filter units are used

For D Block - 2 Coarse mesh Filter and 4 FL Filter units are used

Cost of 1 Coarse mesh filter $=$ Rs 15

Total Cost of 10 Coarse mesh filter $=$ Rs 150

Cost of 1 FL-150 filter Unit= Rs.7000

Total Cost of 20 FL-150 filter Unit= Rs. 140000

Total Cost of filters for Blocks A-D = Rs.140150

Labour Costs

Cost of Masons $=$ Rs 500/day

Cost of Helpers $=$ Rs 300/day

Requirement is 2 Masons and 4 Helpers

For A block:
Tank of Size $-3 \mathrm{~m} \times 1.5 \mathrm{~m} \times 1.5 \mathrm{~m}$ will be built in 6 days

Cost of Helpers $=4 \times 300 \times 6=$ Rs 7200

Cost of Masons $=2 \times 500 \times 6=$ Rs 6000

For B block:

Tank of Size $-6 \mathrm{~m} \times 3 \mathrm{~m} \times 1.5 \mathrm{~m}$ will be built in 9 days

Cost of Helpers $=4 \times 300 \times 9=$ Rs 10800

Cost of Masons $=2 \times 500 \times 9=$ Rs 9000

For C block:

Tank of Size $-5 \mathrm{~m} \times 2 \mathrm{~m} \times 2 \mathrm{~m}$ will be built in 7 days

Cost of Helpers $=4 \times 300 \times 7=$ Rs 8400

Cost of Masons $=2 \times 500 \times 7=$ Rs 7000

For D block:

Tank of Size $-4.75 \mathrm{~m} \times 2.25 \mathrm{~m} \times 1.25 \mathrm{~m}$ will be built in 6 days

Cost of Helpers $=4 \times 300 \times 6=$ Rs 7200

Cost of Masons $=2 \times 500 \times 6=$ Rs 6000

Total Labor Cost $=$ Rs.61600

The total labor cost was estimated to be INR 61600. Thereby the total cost associated with the construction of entire rainwater harvesting system including construction, conveyance, filtration and labor costs are INR 523525. The total volume of water required for flushing and sanitary purposes is calculated to be 3801600 liters for all the residential blocks (A-D) for JUIT campus. This amounts to INR 138 per cubic meter of rainwater harvested or (13 paisa for every liter of rainwater harvested) which is negligible.

\section{Cost estimation for rainwater storing tank}

The total amount of water required for sanitation and washing purposes in Block D is 1056000 liters $\left(1056 \mathrm{~m}^{3}\right)$. The total cost associated with construction of rainwater harvesting system including construction, conveyance, and filtration and labor costs for Block D was estimated to be INR 116424. This amounts to INR 110 per cubic meter of rainwater harvested or (10 paisa for every liter of rainwater harvested) which is negligible.

\section{Case Study II: City of Shimla}

\section{Site description}

Shimla, the capital of state of Himachal Pradesh is located at a height of $2000 \mathrm{~m}$ above MSL in 'middle Himalayas'. The whole city of Shimla has a radius of about $15 \mathrm{Km}$, after considering few regions in the close vicinity of the main city of Shimla that are presently considered as the part of Shimla. The highest point in Shimla is called Jakhoo which governs the landscape of whole Shimla, being situated at the top point of the city with an average elevation close to $8000 \mathrm{ft}$. above the sea level. The geographical locations of Shimla city and its character of landscape largely differ between lower and higher part of the Shimla district and Shimla city. The city lies in 'cold and cloudy' climate zones having fairly long winters from October to March with a severe cold spells during two months during which temperature reach almost $0^{\circ} \mathrm{C}$. Summer months (May-June) are pleasant with a maximum temperature around $30^{\circ} \mathrm{C}$. Monsoon periods (July and 
August) result in heavy rainfall. Intervening months have very mild climate.

Shimla is a major tourist destination attracting, national and international tourists and housing more than 50,000 floating population, comprising of tourists and visitors and a permanent population of nearly 0.2 million people. The population of the city has expanded rapidly thereby exerting pressure on the existing infrastructure of the city [24]. A huge number of tourists visit Shimla during the summer months thereby leading to an increase in the water demand. The Himvani [25] report in 2010 reported that the city requires about 42 MLD of water but is supplied with only 30 MLD thereby creating a huge water requirement deficit during the summer months.

Hence, there is a great need to study the water supply system in Shimla city to cater to the existing problem and find suitable alternatives to the problem encountered. The problem is made more complex as there is an existing high subsidy on water in Shimla city, which puts extra financial pressure on the water management principles of the city. As such, RHS is a viable option to address water shortage in Shimla city.

\section{Design analysis}

In the previous case study, we have seen that the volume of rainwater harvested is suitable for washing and sanitation purposes, thereby we keep our same assumptions and assume that the water demand to be supplied by rainwater is limited in this case study to toilet flushing which is assumed to occur at a constant rate. This assumption is reasonable because the demand time series generated by Water Closet (WC) usage does not exhibit excessive daily variances [26]. We used the same rainfall data as described in the previous case study. Further, we have also calculated the average monthly rainfall over different yearly intervals to further analyze its effects. This is shown in Table 8 .

Optimum design of the roof top rainwater harvesting system may vary with the local specific constraints \& conditions which would directly or indirectly influence the analysis of performance and the conclusions drawn on the reliability of the system. Thus, the design of Rainwater Harvesting System (RHS) under different environmental conditions can generally be examined as a function of two nondimensional parameters i.e. Demand fraction and Storage fraction. The demand fraction is defined as the ratio D/Q between the average monthly water demand (D) and the average monthly inflow (Q) while the storage fraction is defined as the ratio S/Q between the storage capacity of the storage tank (S) and the average monthly inflow (Q).

The percentage of population using different ways for toilet purposes in Shimla is stated in Table 9 (Municipal Corporation website, Shimla). Out of the total population having access to individual toilet facilities, about $52.8 \%$ use ordinary toilets, $16.7 \%$ use High Efficiency Toilets (HET's) and about $28 \%$ of the population use Ultra-Low-Flow (ULF) toilets. Demand depends solely upon the type of water closet being used.

In general with homes using older toilets, the average flush volume uses about 3.6 gallons (13.6 liters) while the daily use is 18.8 gallons per capita per day (gpcd) or (71.2 lpcd). Homes built with ULF toilets have average flush volumes of 1.6 gallons ( 6 liters) with a daily use of 9.1gpcd or (34.4lpcd). Assuming a family of four people using older toilets will use about 27000 gallons of water annually in toilet flushes while a family with ULF toilets will approximately use 13000 gallons of water annually for toilet flushes which will result in savings of about 14000 gallons per year in toilet flushes. With an HET, a family of four will use approximately 9,000 gallons of water annually for toilet flushing (Home water works website).

\begin{tabular}{|l|l|l|l|l|}
\hline Time Interval & $\mathbf{1 9 0 0 - 1 9 3 0}$ & $\mathbf{1 9 3 0 - 1 9 6 0}$ & $\mathbf{1 9 6 0 - 1 9 9 0}$ & $\mathbf{1 9 9 0 - 2 0 0 9}$ \\
\hline Month & & & & \\
\hline January & 41.04 & 41.39 & 35.84 & 37.49 \\
\hline February & 39.03 & 42.49 & 41.9 & 52.21 \\
\hline March & 31.79 & 33.94 & 45.67 & 36.83 \\
\hline April & 28.39 & 29.95 & 32.71 & 35.47 \\
\hline May & 36.61 & 34.57 & 40.96 & 42.27 \\
\hline June & 129.01 & 130.59 & 122.54 & 108.9 \\
\hline July & 246.38 & 285.33 & 282.79 & 177.22 \\
\hline August & 246.6 & 227.57 & 240.1 & 175 \\
\hline September & 148.76 & 140 & 140.21 & 113.73 \\
\hline October & 15.55 & 23.74 & 21.86 & 10.04 \\
\hline November & 12.88 & 9.75 & 10.62 & 11.97 \\
\hline December & 16.05 & 15.84 & 17.66 & 12.49 \\
\hline Standard Deviation & 88.06 & 91.28 & 91.54 & 60.75 \\
\hline
\end{tabular}

Table 8: Monthly average rainfall for period 1900 to 2012

\begin{tabular}{|l|l|}
\hline Type & Percentage (\%) \\
\hline Individual Toilets & 85.15 \\
\hline Open Defecation & 2.31 \\
\hline Public Toilets & 12.42 \\
\hline Standard Deviation & 45.19 \\
\hline
\end{tabular}

Table 9: Percentage of population using different ways of sanitation in Shimla

In general, the area of roof in Shimla is around $150 \mathrm{~m}^{2}$. Considering the above distribution of different types of flushing systems, the total amount of water required (for a family of four) will be about around $70 \mathrm{~m}^{3}$. Hence, the monthly water demand requirement is $5.83 \mathrm{~m}^{3}$. It is assumed that the dimension of the storage tank is $12 \mathrm{~m}^{3}$. Using this information and equation 1 the value of ' $Q$ ' was determined; similarly the demand and storage fraction for the different time period over the century has been computed and all this data has been presented in Table 10.

The variations of the demand and storage fraction with the different selected time intervals have been presented in Figure 10. 


\begin{tabular}{|l|l|l|l|l|}
\hline Time interval & Average Monthly Rainfall $(\mathbf{m m})$ & $\mathbf{Q}\left(\mathbf{m}^{3}\right)$ & Demand Fraction & Storage Fraction \\
\hline $1900-1930$ & 82.67 & 10.54 & 0.55 & 1.138 \\
\hline $1930-1960$ & 84.6 & 10.79 & 0.537 & 1.112 \\
\hline $1960-1990$ & 86.07 & 10.97 & 0.528 & 1.093 \\
\hline $1990-2009$ & 67.8 & 8.64 & 0.671 & 1.388 \\
\hline $1900-2009$ & 81.54 & 10.38 & 0.559 & 1.156 \\
\hline Standard Deviation & 7.33 & 0.94 & 0.06 & 0.12 \\
\hline
\end{tabular}

Table 10: Computation of Demand and Storage fraction for over certain time intervals (in years)

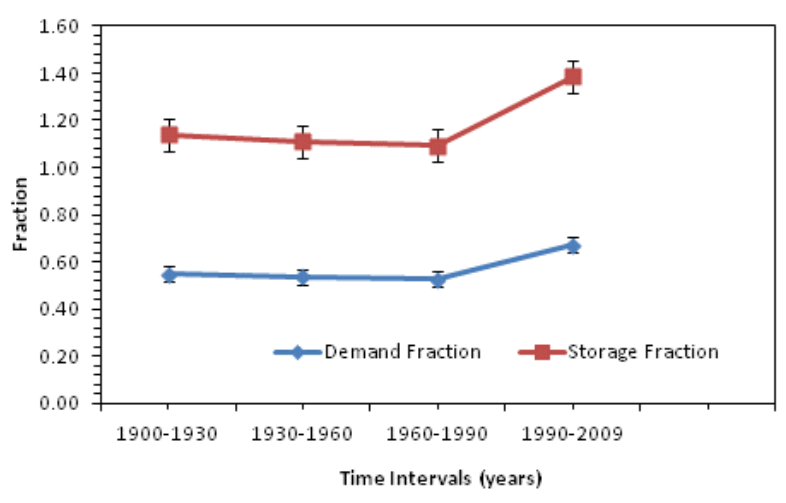

Figure 10: Variation of Demand and Storage Fraction with different time intervals.

\section{Results and Discussions}

\section{Case study - I}

Case study I show that if we consider the total volume of rainwater harvested at the JUIT campus over a year, it will be sufficient enough to cater to sanitation and washing requirements for all the people living in block D throughout the year. This would lead to substantial savings for the University, as the water bill along with power consumption will be greatly reduced leading to financial savings.

Water quality parameters analyzed for the rainwater collected includes $\mathrm{pH}$ which is defined as the negative logarithmic of hydrogen ions concentration. The $\mathrm{pH}$ test is an important preliminary test as small changes in $\mathrm{pH}$ ( 0.3 units or even less) are generally associated with relatively large changes in other water qualities. Natural waters have $\mathrm{pH}$ ranges varying from 5.0 to 8.5 . Turbidity is a measure of water clarity including how much the material suspended in water decreases the passage of light through the water and is an important consideration for disinfection of water. Hardness in water causes encrustation in pipes and can reduce the effective life of the pipe system; thereby hardness is an important parameter that needs to be measured to maintain the efficiency and longevity of connecting pipe network of the rainwater harvesting system. Other important parameters analyzed included acidity and alkalinity and Total Dissolved Solids (TDS). The results have been presented in Table 11.

\begin{tabular}{|l|l|l|}
\hline Water Quality Parameters & Results & Indian Standards \\
\hline pH & 7.2 & $6.6-8.5$ \\
\hline Turbidity & $8 \mathrm{NTU}$ & $5-10 \mathrm{NTU}$ \\
\hline Hardness & $46.5 \mathrm{mg} / \mathrm{l}$ & $75-200 \mathrm{mg} / \mathrm{l}$ \\
\hline Alkalinity & $50 \mathrm{mg} / \mathrm{l}$ & Max of $200 \mathrm{mg} / \mathrm{l}$ \\
\hline Acidity & $0 \mathrm{mg} / \mathrm{l}$ & - \\
\hline TDS & $10 \mathrm{mg} / \mathrm{l}$ & Max of $500 \mathrm{mg} / \mathrm{l}$ \\
\hline Chloride & $1.2 \mathrm{mg} / \mathrm{l}$ & Max of $250 \mathrm{mg} / \mathrm{l}$ \\
\hline
\end{tabular}

Table 11: Water Quality Parameters for Rainwater Harvested at JUIT campus

The water quality analysis results shows that the rainwater collected is reasonably good quality with values of the parameters much less than the prescribed Indian Standards. However, since the collected rainwater is to be utilized as non-potable sources for the purpose of washing and sanitation, the actual quality of water is not particularly of great concern. Water quality analysis of harvested rainwater at different locations also shows similar ranges of values for the different parameters considered [27].

The benefit cost analysis computed showed that the total cost associated with the construction of the rainwater harvesting system would be about INR 138 per cubic meter of rainwater harvested to be used for washing and sanitation purposes for all residential blocks (AD) in JUIT which is negligible. If we consider only residential Block D, the total cost would be only a minimum of INR 110 per cubic meter of rainwater harvested. The total cost of water per liter would amount to only 11 paisa per liter for Block - D (13 paisa per liter for Block A-D) and is comparable to value of 20 paisa per liter reported by Samuel and Satapathy [15] for rainwater harvesting systems in North-eastern states of India.

The benefit cost ratio analysis shows that within a minimum period the installation cost of the rainwater harvesting system can be easily recovered. Further added advantages of including a RHS system would include exemption of paying water bill (or tanker charges) as well as make any potential savings on any changes in the rate of the water pricing or additional taxes charged by the local municipal corporations if rainwater is daily utilized for washing and sanitation facilities. Comparing benefit costs ratio between traditional water supply systems and rainwater harvesting systems reveal that rainwater 
harvesting is a cost effective technology. Further, proper implementation of RHS could also lead to substantial decrease in consumption of power [28].

\section{Case study - II}

The source of water for Shimla city is located at very great distance and in the coming years the local municipal corporation will not be able to account for the increased rise in expenses as the present rate of supply costs have already exceeded the limits and no extra resources are available. Recent reports suggest that the present cost of production and supply of water is almost the six times the cost charged by the municipal corporation thereby making the costs untenable in the coming future years. Further, with increase in population in Shimla and growing influx of tourists during summer, the shortage of water supply is highly acute during the summer months.

As such, RHS is a suitable alternative option [29], particularly because the months of June to September account for almost $75 \%$ of total rainfall experienced by Shimla. The average monthly rainfall variation in the Shimla observed from a century of data has been shown in Figure 11. Singh and Kandari (2008) reported that the total mean annual rainfall for based on the last 25 years dataset was 1437.1 $\mathrm{mm}(1980$ - 2005) whereas our analysis showed that the mean annual rainfall was $977 \mathrm{~mm}(1900-2012)$.

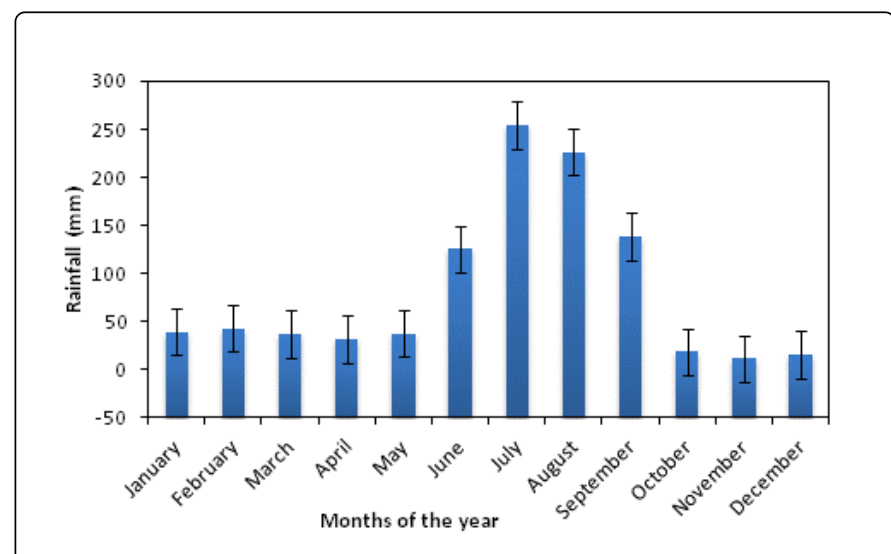

Figure 11: Monthly Rainfall Variation in Shimla (from 1900 - 2012)

In this context, Case study II (Shimla city) shows that the computation of demand and storage fraction is a suitable basis for computing the requirements and utilization of the total volume of rainwater harvested [30]. Further, a simple efficiency analysis has also been computed. For example, let us consider the volume of storage tank as ' $\mathrm{V}$ ' at the starting of the month and the total amount of rainwater supplied from the storage tank as ' $\mathrm{Y}$ '

$$
V=Q-D
$$

Let us consider the period 1990-2009; the value of 'Q' as observed from Table 10 is $10.38 \mathrm{~m}^{3}$. The monthly water demand (D) has already been computed as $5.83 \mathrm{~m} 3$. Hence the volume of storage tank is now $4.55 \mathrm{~m}^{3}$.

The total amount of rainwater to be supplied will be the minimum of ' $V$ ' and ' $D$ '

$$
Y=\operatorname{Min}(V, D)
$$

Hence the value of $\mathrm{Y}$ is $4.55 \mathrm{~m} 3$. Hence, the efficiency value can be calculated as

$$
=Y / D
$$

The efficiency value was found to be $79.3 \%$.

The value of efficiency is very high considering the mean rainfall value. Though we have made reasonable assumptions while selecting the design parameters and storage capacities the results show that rainwater harvested for one month will be sufficient to meet the demand of that for a family of four for toilet flushing and that RHS is a suitable alternative for meeting the city's excess water requirement.

\section{Limitations}

One of the major criticisms of rainwater harvesting is the lack of dependency and unreliability of rainfall and its supplemental role as opposed to a full replacement role for meeting water demand. Further, problems may arise due to chemical and microbiological contamination, the hazards of stagnant water and breeding of mosquitoes, the uneconomical aspects of rainwater harvesting and bad cost-benefit ratios.

Rainwater Harvesting System (RHS) is often site specific and depends on local rainfall hence it is difficult to give a generalized idea and make it successful. Household based RHS is used to meet some of the water demand requirements but it rarely ever manages to satisfy the full daily water requirement demands. RHS can provide chance to use water for other purpose like bathing, washing, irrigation but the maintenance of this types of RHS is difficult. Further, incorrect prediction of rainfall can make the system unusable. In public supply situations it is often not possible to have adequate management systems in place and often RHS are not maintained properly and more often they become the user right of some specific households.

\section{Conclusions}

The northern part of country experiences a huge shortage of water during summer seasons leading to acute problems. A concerted effort is needed to solve the problem as it cannot be solved with immediate effect. In such a scenario, rainwater harvesting system is a viable option to supplement the city's water requirement. This paper attempts to focus on the sustainability and effectiveness of a rainwater harvesting system in terms of quality and it's a proper utilization. Two case studies have been considered, case I shows the design analysis and utilization of the rainwater harvested for JUIT campus. The results show that the total volume of rainwater harvested will meet $30 \%$ of the total water demand requirement annually for washing and sanitation purposes. Further, if we consider only one residential block (block D), the total volume of rainwater harvested is sufficient to meet the flushing and sanitation requirements for persons living in the block. The overall quality of rainwater was quite satisfactory and meets the criteria for its purpose of washing and sanitation. Additionally, the system is cost effective as large amounts of money can be saved per year as shown from the benefit-cost analysis. Case II presents the design analysis and concept for a rooftop RHS in Shimla city and its effectiveness in serving the washing and sanitation purposes in the city for the current scenario. In addition, we have introduced two nondimensional parameters Demand fraction and Storage fraction which can be used as guidelines for design of rainwater harvesting systems. Since application of RHS is very site specific depending upon the amount of rainfall both demand and storage fraction may vary and 
proper optimization needs to be done to make it more effective. The efficiency of the system was observed to be about $79 \%$ for the case study in Shimla.

\section{References}

1. Rockstrom J, Karlberg L, Wani SP, Barron J, Hatibu N, et al. (2009) Managing Water in Rainfed Agriculture: The Need for a Paradigm Shift. Agriculture Water Management 97: 543-550.

2. Intergovernmental Panel on Climate Change [IPCC] (2007) Climate Change 2007. Fourth Assessment Report, Cambridge University Press, Cambridge, UK.

3. Alpana K (2003) Groundwater Recharge: Need of the Day. Kanchan Chopra, C.H. Hanumantha Rao, and Ramprasad Sengupta edn. Water Resources, Sustainable Livelihoods and Eco-System Services, Concept Publishing Company, New Delhi 194-203.

4. Kim RH, Lee S, Lee JH, Kim YM, Suh JY (2005) Developing technologies for rainwater utilization in urbanized areas. Environ Technol 26: 401-410.

5. Hatibu N, Mahoo H (2001) Rainwater harvesting technologies for agricultural production: A case for Dodoma, Tanzania. Sokoine University of Agriculture. Department of Agricultural Engineering and Land Planning, Morogoro, Tanzania.

6. Patil AK, Patil GK (2006) Rainwater Harvesting Techniques. Conference paper presented at National Seminar on Rainwater Harvesting and Water Management, Nagpur, India.

7. Handia L, Tembo JM, Mwiindwa C (2003) Potential of rainwater harvesting in urban Zambia.Physics and Chemistry of the Earth 28: 893896.

8. Water Harvesting (2014) Traditional Systems, Rain water harvesting organization, India.

9. Kishore R, Singh DK, Singh RM, Singh R, Bhandarkar DM (2005) Restructuring of Water Harvesting Ponds and Ground Water Recharge. NC Patel, R Subbaiah, PM Chauhan, KC Patel and JN Nandasana edn Sustainable Management of Water Resources, Himanshu Publications, Udaipur, 208-214.

10. Shah T, Raju KV (2001) Rethinking Rehabilitation: Socio-Ecology of Tanks and Water Harvesting in Rajasthan, North West India. CAPRi Working Paper No. 18, CGIAR System-wide Project on Collective Action and Property Rights. International Food Policy Research Institute (IFPRI), Washington DC, USA.

11. Khurana I (2003) Water Scarcity? Try Capturing the Rain. Kamta Prasad edn. Water Resources and Sustainable Development, Shipra Publications, Delhi 137-47.

12. Verma S, Van Der Zaag P, Uhlenbrook S (2008) Small Reservoirs, Big Impacts? Exploring Alternate Models of River Basin Development. Draft Paper for discussion presented at the 2nd International Forum on Water and Food, Addis Ababa, Ethiopia.

13. Tilala H, Shiyani RL (2005) Economic Impact of Water Harvesting Structures on Farmers of North Saurashtra Agro-Climatic Zone. N.C.
Patel, R. Subbaiah, P.M. Chauhan, K.C. Patel, and J.N. Nandasana edn Sustainable Management of Water Resources, Himanshu Publications, Udaipur, India.

14. Central Ground Water Board, Ministry of Water Resources (2011) Select Case Studies of Rainwater Harvesting and Artificial Recharge. Report prepared by Central Ground Water Board, Ministry of Water Resources, India.

15. Samuel MP, Satapathy KK (2008) Concerted Rainwater Harvesting Technologies suitable for hilly agro-ecosystems of Northeast India. Current Science 95: 1130-1132.

16. Senkondo EMM, Msangi ASK, Xavery P, Lazaro EA, Hatibu N (2004) Profitability of Rainwater Harvesting for Agricultural Production in Selected Semi-Arid Areas of Tanzania. J Applied Irrigation Science 39: 65-81.

17. Goel AK, Kumar R (2005) Economic Analysis of water harvesting in mountainous watershed in India. Agricultural Water Management 71: 257-266.

18. Haitbu N, Mutabazi K, Senkondo EM, Msangi ASK (2006) Economics of rainwater harvesting for crop enterprises in semi-arid areas of East Africa. Agricultural Water Management 80: 74-86.

19. Gnecco I, Berretta C, Lanza LG, La Barbera P (2006) Quality of storm water runoff from paved surfaces of two production sites. Water Sci Technol 54: 177-184.

20. Khastagir A, Jayasuriya N (2010) Optimal sizing of rain water tanks for domestic water conservation. Journal of Hydrology 381: 181-188.

21. Basinger M, Montalto F, Upmanu L (2010) A rainwater harvesting system reliability model based on nonparametric stochastic rainfall generator. Journal of Hydrology 392: 105-111.

22. Gnecco I, Berretta C, Lanza LG, La Barbera P (2005) Storm water pollution in the urban environment of Genoa, Italy. Atmospheric Research 77: 60-73.

23. Mosley L (2005) Water quality of Rainwater Harvesting Systems.

24. Singh T, Kandari LS (2014) Rainwater Harvesting in the Wake of Climate Change: A case study from Shimla city, Himachal Pradesh. Universal Journal of Environmental Science and Technology 2: 336-346.

25. Himvani (2010) Normal water supply to Shimla restored. Himvani, India.

26. Fewkes A (2000) Modelling the performance of rainwater collection systems: towards a generalised approach. Urban Water 1:323-333.

27. Despins C, Farahbahks, K, Leidl C (2009) Assessment of rainwater quality from rainwater harvesting systems in Ontario, Canada. Journal of Water Supply: Research and Technology - AQUA, 58.2, 117-134.

28. Rahman S, Khan MTR, Akib S, Din NBC, Biswas SK, et al. (2014) Sustainability of Rainwater Harvesting System in terms of Water Quality. The Scientific World Journal.

29. Shrivastava SK, Khurana I (2009) Revival of hill towns through rainwater harvesting. European Rainwater Catchment System Association.

30. Municipal Corporation Shimla (2014) Rainwater harvesting, Municipal Corporation, Shimla, India. 